\title{
Merocyanine Dyes with Improved Photostability
}

\author{
Alexei Toutchkine ${ }^{1,2}$, Dan-Vinh Nguyen ${ }^{3}$, Klaus Hahn ${ }^{1,3}$
}

${ }^{1}$ to whom correspondence should be addressed

${ }^{2}$ Present address: Sigma-Aldrich Co, 3 Strathmore Rd, Natick, MA 01760, USA

E-mail: alexei.toutchkine@sial.com, khahn@med.unc.edu

${ }^{3}$ University of North Carolina at Chapel Hill, Department of Pharmacology and Lineberger Cancer Center, Chapel Hill, North Carolina 27599, USA

\section{General Aspects}

Materials. Analytical grade reagents were purchased from Sigma-Aldrich Co. (2Z)-2-[(2E)-3-methoxyprop-2en-1-ylidene]-1-benzothiophen-3(2H)-one 1,1-dioxide, (2Z)-2-[(2E,4Z)-4-(3-ethyl-1,3-benzothiazol-2(3H)ylidene)but-2-en-1-ylidene]-1-benzothiophen-3(2H)-one 1,1-dioxide (S-SO), (2Z)-2-[(2E,4E)-4-(1,3,3trimethyl-1,3-dihydro-2H-indol-2-ylidene)but-2-en-1-ylidene]-1-benzothiophen-3(2H)-one 1,1-dioxide (I-SO) were prepared as previously described ${ }^{1}$.

Methods. Absorption spectra were recorded on a Hewlett-Packard 8453 diode array UV-Vis spectrophotometer, and fluorescence measurements were taken on a Spex Fluorolog 2 spectrofluorometer. Melting poins are not corrected. NMR spectra were obtained on a Varian Mercury $300 \mathrm{MHz}$ or on a Bruker 300 MHz DRX 300 spectrometer. Mass spectra were obtained on a Hewlett-Packard 1100 high-performance liquid 
chromatograph equipped with an 1100 mass selective detector (MS-ESI). Quantum yields were measured using merocyanine 540 or $\mathrm{Cy} 5$ as an internal standards.
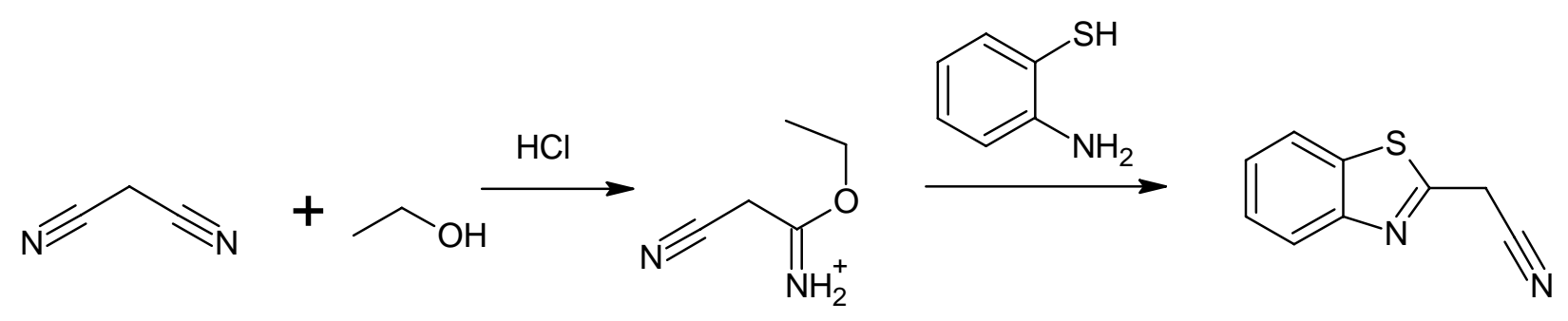

\section{1,3-bezothiazol-2-ylacetonitrile}

To a solution of malonodinitrile $(13.22 \mathrm{~g}, 0.200 \mathrm{~mole})$ in dry chloroform $(100 \mathrm{~mL})$ was added ethanol $(9.2 \mathrm{~g}$, 0.200 mole). Hydrogen chloride ( $8.0 \mathrm{~g}, 0.220$ mole) was passed into the solution at room temperature and the resulting suspension was stirred for an additional 16 hours at room temperature. The excess of hydrogen chloride was removed by passing dry nitrogen into the reaction mixture. A solution of o-aminothiophenol ( $25 \mathrm{~g}$, 0.200 mole) in chloroform was added to the reaction mixture dropwise during $30 \mathrm{~min}$ and the reaction mixture was stirred for 1 hour at $60 \mathrm{C}$. After that the reaction mixture was cooled to room temperature, washed with water $(2 * 100 \mathrm{~mL})$ and dried with magnesium sulfate. Chloroform was removed using a rotary evaporator. The solid residue was recrystallized from ethyl alcohol. White crystals. The yield was $26.1 \mathrm{~g}$ ( $75 \%$ of theory).

$\mathrm{Mp}=101-103 \mathrm{C}$

${ }^{1} \mathrm{H} \mathrm{NMR}\left(\mathrm{CDCl}_{3}, 300 \mathrm{MHz}\right) \delta 4.24(\mathrm{~s}, 2 \mathrm{H}), 7.44\left(\mathrm{t},{ }^{3} \mathrm{~J}_{\mathrm{H}-\mathrm{H}}=7.8 \mathrm{~Hz}, 1 \mathrm{H}\right), 7.53\left(\mathrm{t},{ }^{3} \mathrm{~J}_{\mathrm{H}-\mathrm{H}}=7.8 \mathrm{~Hz}, 1 \mathrm{H}\right), 7.89(\mathrm{~d}$, $\left.{ }^{3} \mathrm{~J}_{\mathrm{H}-\mathrm{H}}=7.8 \mathrm{~Hz}, 1 \mathrm{H}\right), 8.04\left(\mathrm{~d},{ }^{3} \mathrm{~J}_{\mathrm{H}-\mathrm{H}}=7.8 \mathrm{~Hz}, 1 \mathrm{H}\right)$.

${ }^{13} \mathrm{C} \mathrm{NMR}\left(\mathrm{CDCl}_{3}, 75 \mathrm{MHz}\right) \delta 22.3,116.4,122.2,122.5,125.5,126.4,135.0,152.2,160.4$.

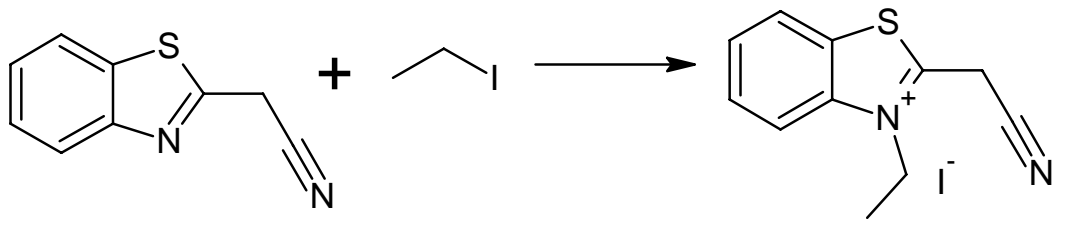




\section{2-(cyanomethyl)-3-ethyl-1,3-benzothiazol-3-ium iodide}

A solution of 1,3-bezothiazol-2-ylacetonitrile (10 g, $0.057 \mathrm{~mole})$ in iodoethane $(10 \mathrm{~mL}, 0.125$ mole) was heated in sealed tube at $120 \mathrm{C}$ for 36 hours. The precipitated solid was filtered, washed with ether $(100 \mathrm{~mL})$ and dried. The yield was $10 \mathrm{~g}$ (53\% of theory).

${ }^{1} \mathrm{H}$ NMR (DMSO-d 6 , $\left.300 \mathrm{MHz}\right) \delta 1.31\left(\mathrm{t},{ }^{3} \mathrm{~J}_{\mathrm{H}-\mathrm{H}}=7.0 \mathrm{~Hz}, 3 \mathrm{H}, \mathrm{CH}_{3} \mathrm{CH}_{2^{-}}\right), 3.93\left(\mathrm{q},{ }^{3} \mathrm{~J}_{\mathrm{H}-\mathrm{H}}=7.0 \mathrm{~Hz}, 2 \mathrm{H}, \mathrm{CH}_{3} \mathrm{CH}_{2^{-}}\right.$ ), $4.76\left(\mathrm{~s}, \mathrm{CH}_{2}-\mathrm{CN}\right), 7.09\left(\mathrm{t},{ }^{3} \mathrm{~J}_{\mathrm{H}-\mathrm{H}}=7.5 \mathrm{~Hz}, 1 \mathrm{H}\right), 7.23\left(\mathrm{t},{ }^{3} \mathrm{~J}_{\mathrm{H}-\mathrm{H}}=7.5 \mathrm{~Hz}, 1 \mathrm{H}\right), 7.31\left(\mathrm{~d},{ }^{3} \mathrm{~J}_{\mathrm{H}-\mathrm{H}}=7.5 \mathrm{~Hz}, 1 \mathrm{H}\right), 7.58$ $\left(\mathrm{d},{ }^{3} \mathrm{~J}_{\mathrm{H}-\mathrm{H}}=7.5 \mathrm{~Hz}, 1 \mathrm{H}\right)$.

${ }^{13} \mathrm{C}$ NMR (DMSO-d, $\left.75 \mathrm{MHz}\right) \delta 11.9,55.1,111.3,122.0,123.2,123.9,127.8,142.2,162.1$.
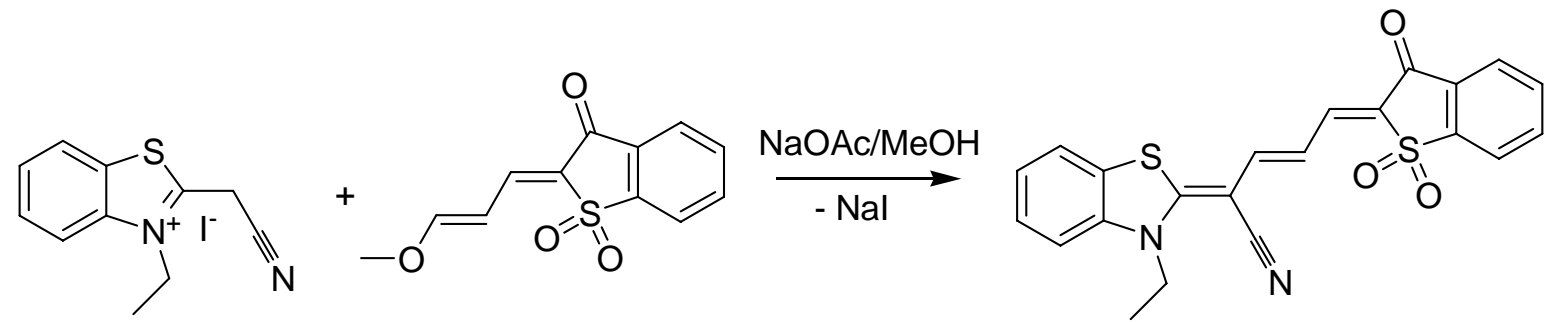

(2E,3E,5Z)-5-(1,1-dioxido-3-oxo-1-benzothien-2(3H)-ylidene)-2-(3-ethyl-1,3-benzothiazol-2(3H)ylidene)pent-3-enenitrile (S-SO-CN).

In a one-necked round bottom $100 \mathrm{~mL}$ flask equipped with magnetic stir bar and reflux condenser were added 2-(cyanomethyl)-3-ethyl-1,3-benzothiazol-3-ium iodide (1.00 g, $3.03 \mathrm{mmol})$, (2Z)-2-[(2E)-3-methoxyprop-2en-1-ylidene]-1-benzothiophen-3(2H)-one 1,1-dioxide $(1.00 \mathrm{~g}, 4.00 \mathrm{mmol})$ and $\mathrm{CHCl}_{3}-\mathrm{MeOH}_{\text {mixture }}(1: 1,20$ $\mathrm{mL}$ ). The flask was heated on an oil bath with stirring until boiling began, and a solution of sodium acetate (320 $\mathrm{mg}, 4.00 \mathrm{mmol}$ ) in $10 \mathrm{ml}$ of methanol was added to the flask. The stirring was continued under reflux for an additional $30 \mathrm{~min}$. The flask was cooled to room temperature and the precipitated solid was filtered, washed with methanol and dried. Green crystals. The yield was $730 \mathrm{mg}$ (57\% of theory).

${ }^{1} \mathrm{H} \mathrm{NMR}\left(\mathrm{CDCl}_{3}, 300 \mathrm{MHz}\right) \delta 1.49\left(\mathrm{t},{ }^{3} \mathrm{~J}_{\mathrm{H}-\mathrm{H}}=7.2 \mathrm{~Hz}, 3 \mathrm{H}\right), 4.71\left(\mathrm{q},{ }^{3} \mathrm{~J}_{\mathrm{H}-\mathrm{H}}=7.2 \mathrm{~Hz}, 2 \mathrm{H}\right), 6.78\left(\mathrm{t},{ }^{3} \mathrm{~J}_{\mathrm{H}-\mathrm{H}}=12.9 \mathrm{~Hz}\right.$, $1 \mathrm{H}), 7.47\left(\mathrm{t},{ }^{3} \mathrm{~J}_{\mathrm{H}-\mathrm{H}}=7.5 \mathrm{~Hz}, 1 \mathrm{H}\right), 7.61\left(\mathrm{t},{ }^{3} \mathrm{~J}_{\mathrm{H}-\mathrm{H}}=7.5 \mathrm{~Hz}, 1 \mathrm{H}\right), 7.8-8.2(\mathrm{~m}, 8 \mathrm{H})$. 
ESI-MS: $421\left(\mathrm{MH}^{+}\right)$.

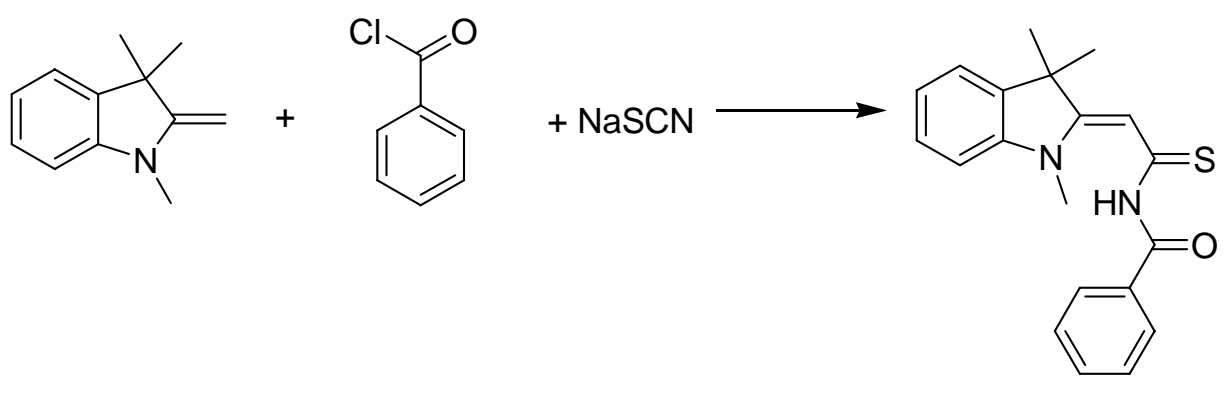

\section{$N$-[(2Z)-2-(1,3,3-trimethyl-1,3-dihydro-2H-indol-2-ylidene)ethanethioyl]benzamide}

A two-necked round bottom $500 \mathrm{~mL}$ flask was equipped with a magnetic stir bar, additional funnel and a reflux condenser. To the flask were added sodium thiocyanate $(8.1 \mathrm{~g}, 0.10$ mole) and dry acetone $(100 \mathrm{~mL})$. The stirring was started and benzoyl chloride $(14.1 \mathrm{~g}, 0.1$ mole) was added to the flask by drops. When the addition of benzoyl chloride was complete the flask was heated on an oil bath with stirring until boiling began and the flask contents were stirred under reflux for an additional 30 minutes. The oil bath was removed and 3,3trimethyl-2-methyleneindoline $(15.8 \mathrm{~g}, 0.10 \mathrm{~mole})$ was added to the flask by drops. After completion of the addition the flask was heated again on an oil bath for an additional $30 \mathrm{~min}$ at reflux. The flask was cooled to room temperature and the reaction mixture was poured in $1 \mathrm{~L}$ beaker containing $500 \mathrm{~mL}$ of water. The precipitated solid was filtered, washed with water and dried. The product was purified by recrystallization from methanol. The yield was $19.1 \mathrm{~g}(57 \%$ of theory).

$\mathrm{Mp}=108-110 \mathrm{C}$

${ }^{1} \mathrm{H} \mathrm{NMR}\left(\mathrm{CDCl}_{3}, 300 \mathrm{MHz}\right) \delta 1.76(\mathrm{~s}, 6 \mathrm{H}), 3.75(\mathrm{~s}, 3 \mathrm{H}), 7.19\left(\mathrm{~d},{ }^{3} \mathrm{~J}_{\mathrm{H}-\mathrm{H}}=7.8 \mathrm{~Hz}, 1 \mathrm{H}\right), 7.31\left(\mathrm{t},{ }^{3} \mathrm{~J}_{\mathrm{H}-\mathrm{H}}=7.2 \mathrm{~Hz}\right.$, $1 \mathrm{H}), 7.40-7.46(\mathrm{~m}, 2 \mathrm{H}), 7.60-7.80(\mathrm{~m}, 4 \mathrm{H}), 8.02\left(\mathrm{~d},{ }^{3} \mathrm{~J}_{\mathrm{H}-\mathrm{H}}=6.9 \mathrm{~Hz}, 2 \mathrm{H}\right), 9.31(\mathrm{~s}, 1 \mathrm{H}, \mathrm{NH})$.

${ }^{13} \mathrm{C} \mathrm{NMR}\left(\mathrm{CDCl}_{3}, 75 \mathrm{MHz}\right) \delta 25.8,37.2,49.5,99.2,110.0,122.0,124.1,127.2,127.9,128.7,132.3,133.9$, $139.8,144.6,163.7,177.4,185.2$. 

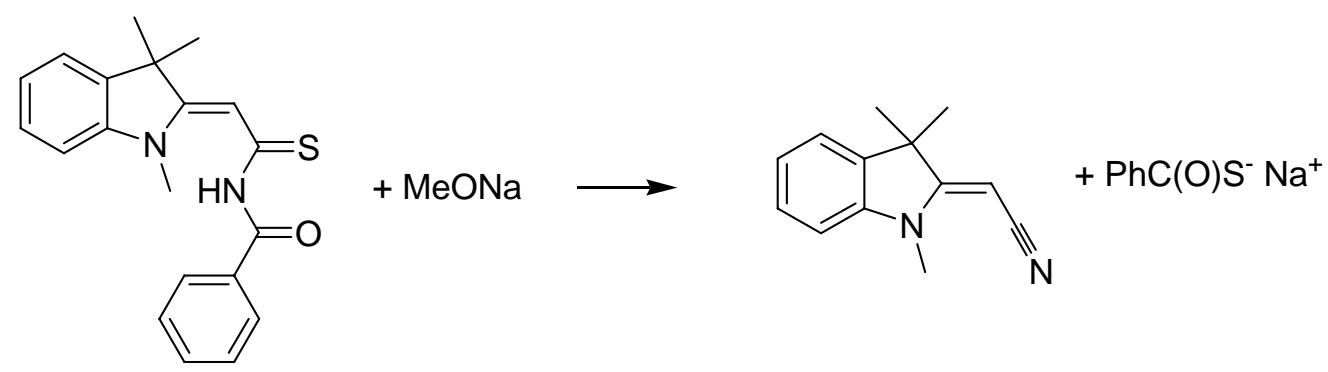

\section{(1,3,3-trimethyl-2,3-dihydro-1H-indol-2-yl)acetonitrile}

A $500 \mathrm{~mL}$ one-necked flask was equipped with a magnetic stir bar and a reflux condenser. $200 \mathrm{~mL}$ of methanol were added to the flask, sodium $(3.0 \mathrm{~g}, 0.13$ mole) was added to the methanol as small pieces $(\sim 0.5 \mathrm{~g})$. After the sodium dissolved, $\mathrm{N}$-[(2Z)-2-(1,3,3-trimethyl-1,3-dihydro- $2 H$-indol-2-ylidene)ethanethioyl]benzamide (19.0 g, 0.056 mole) was added to the flask and the reaction mixture was heated at reflux with stirring for 2 hours. The reaction mixture was cooled to room temperature and the methanol was evaporated using a rotary evaporator. The residue was treated with $200 \mathrm{~mL}$ of water and extracted with dichoromethane $(3 * 100 \mathrm{~mL})$. Combined organic extracts were dried over magnesium sulfate and solvent was evaporated on a rotary evaporator. The red solid was recrystallized from methanol-water (7:3) to give slightly red crystals. The yield was $4.5 \mathrm{~g}$ ( $40 \%$ of theory).

$\mathrm{Mp}=74-76 \mathrm{C}$.

${ }^{1} \mathrm{H}$ NMR (dmso-d6, $\left.300 \mathrm{MHz}\right) \delta 1.55\left(\mathrm{~s}, 6 \mathrm{H}, 2 * \mathrm{CH}_{3}\right), 3.13\left(\mathrm{~s}, 3 \mathrm{H}, \mathrm{CH}_{3}\right), 4.48(\mathrm{~s}, 1 \mathrm{H}, \mathrm{CH}-\mathrm{CN}), 6.85-7.0(\mathrm{~m}$, $2 \mathrm{H}), 7.21\left(\mathrm{t},{ }^{3} \mathrm{~J}_{\mathrm{H}-\mathrm{H}}=7.7 \mathrm{~Hz}, 1 \mathrm{H}\right), 7.31\left(\mathrm{~d},{ }^{3} \mathrm{~J}_{\mathrm{H}-\mathrm{H}}=6.9 \mathrm{~Hz}, 1 \mathrm{H}\right)$.

${ }^{13} \mathrm{C}$ NMR (dmso-d6, 75 MHz) $\delta 25.3,28.9,46.3,57.6,107.4,120.2,121.3,121.7,137.1,143.6,171.9$.

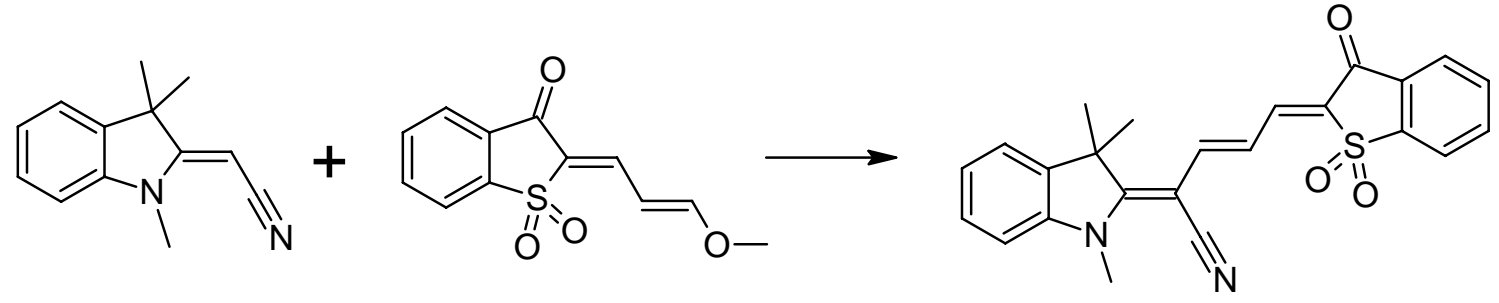


(2Z,3E,5Z)-5-(1,1-dioxido-3-oxo-1-benzothiophen-2(3H)-ylidene)-2-(1,3,3-trimethyl-1,3-dihydro-2Hindol-2-ylidene)pent-3-enenitrile (I-SO-CN).

A mixture of (1,3,3-trimethyl-2,3-dihydro-1 $H$-indol-2-yl)acetonitrile (397 mg, $2.00 \mathrm{mmol})$ and (2Z)-2-[(2E)-3methoxyprop-2-en-1-ylidene]-1-benzothiophen-3(2H)-one 1,1-dioxide (501 mg, $2.00 \mathrm{mmol})$ were placed in a $10 \mathrm{~mL}$ one-necked round bottom flask. The flask was heated in an oil bath at $210 \mathrm{C}$ for 2 hours and then cooled to room temperature. The reaction mixture was extracted with dichloromethane $(100 \mathrm{~mL})$. The organic solution was passed through a short silica column, the dichloromethane was evaporated and the pure dye was obtained by recrystallization from methanol. The yield was $511 \mathrm{mg}$ of green crystals ( $63 \%$ of theory).

${ }^{1} \mathrm{H}$ NMR $\left(\mathrm{CDCl}_{3}, 300 \mathrm{MHz}\right) \delta 1.68\left(\mathrm{~s}, 6 \mathrm{H}, 2 * \mathrm{CH}_{3}\right), 3.86\left(\mathrm{~s}, 3 \mathrm{H}, \mathrm{CH}_{3}\right), 6.89\left(\mathrm{t},{ }^{3} \mathrm{~J}_{\mathrm{H}-\mathrm{H}}=13.1 \mathrm{~Hz}, 1 \mathrm{H}\right), 7.1-8.4(\mathrm{~m}$, $10 \mathrm{H})$.

ESI-MS: $431\left(\mathrm{MH}^{+}\right)$. 


\section{Photobleaching experiments.}

$15 \mathrm{~mL}$ of $0.01 \mathrm{mM}$ solution of dye in methanol were placed in a $20 \mathrm{~mL}$ Borosilicate Glass Scintillation Vial (Fisher catalog \# 03-337-15). The vial was illuminated by filtering through glass the light of a 90W halogen reflector lamp (120 V, 1280 Lumens, 12 Degree Beam Spread). The distance between the vial and the lamp was $11.0 \mathrm{~cm}$. A fan $(120 \mathrm{~V}, 150 \mathrm{~mm}))$ was used to cool the vial. At time intervals a sample was removed and the sample absorbance spectra was obtained on a Hewlett-Packard 8453 diode array spectrophotometer. Rate constants of dye photobleaching were obtained from a plot of $\ln (\mathrm{A})$ vs. time.

Table 1. Photobleaching of S-SO and S-SO-CN dyes.

\begin{tabular}{|l|l|l|l|}
\hline Dye & Time (seconds) & $\mathrm{A}_{\mathrm{t}} / \mathrm{A}_{0}^{\mathrm{a}}$ & $-\ln \left(\mathrm{A}_{\mathrm{t}} / \mathrm{A}_{0}\right)$ \\
\hline S-SO & 0 & 1.0000 & 0.0000 \\
& 66900 & 0.7409 & 0.3000 \\
& 154200 & 0.4485 & 0.8018 \\
& 258300 & 0.2880 & 1.2448 \\
& 349800 & 0.1560 & 1.8579 \\
\hline S-SO-CN & 0 & 1.0000 & 0.0000 \\
& 66900 & 0.9851 & 0.0150 \\
& 154200 & 0.9790 & 0.0212 \\
& 258300 & 0.9613 & 0.0395 \\
& 349800 & 0.9530 & 0.0481 \\
\hline
\end{tabular}

${ }^{a}$ Absorbances were measured at wavelengths equal to $\lambda_{\max }(597 \mathrm{~nm}$ for S-SO and $550 \mathrm{~nm}$ for S-SO-CN) 


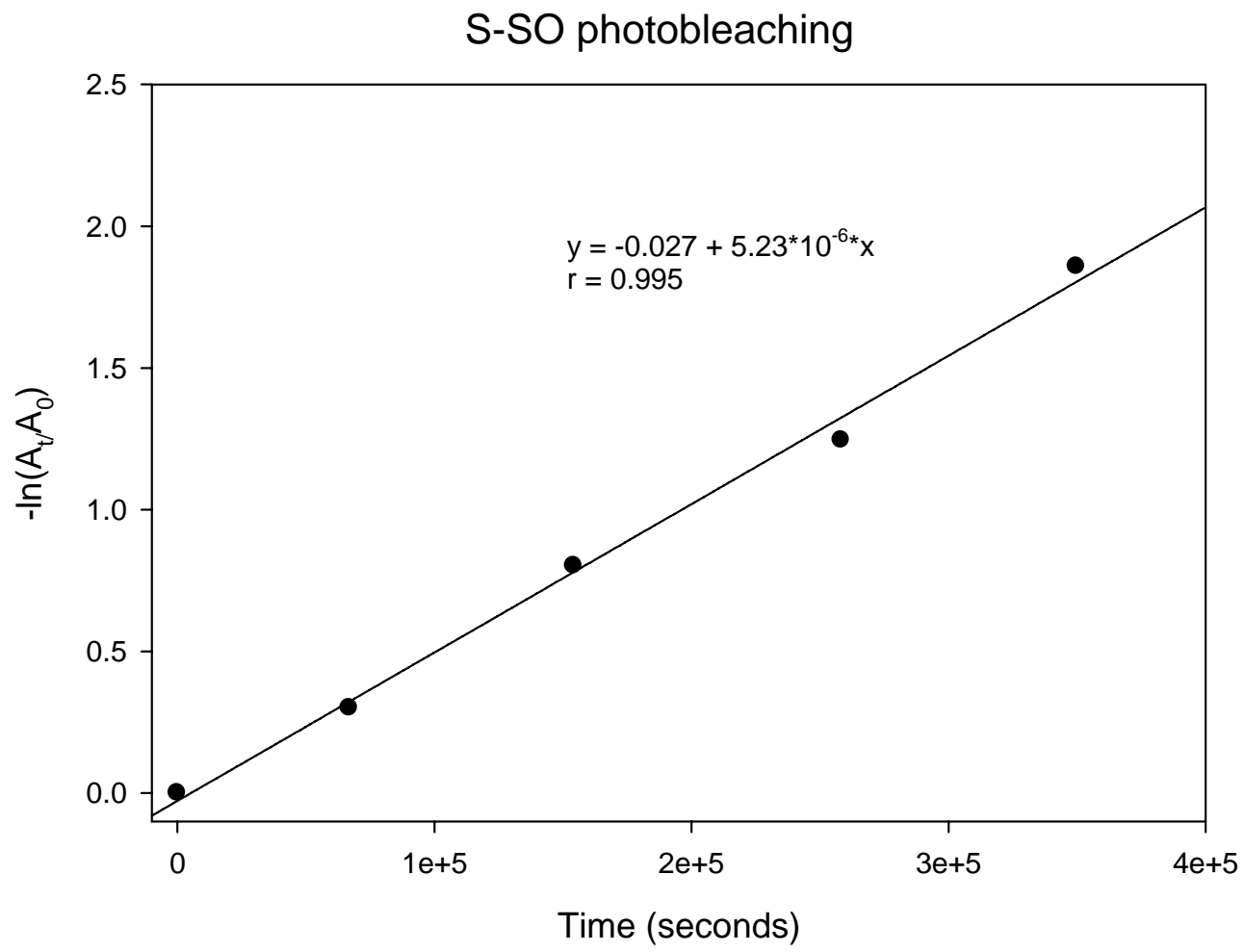

Figure 1. Photobleaching of S-SO dye. 


\section{S-SO-CN Photobleaching}

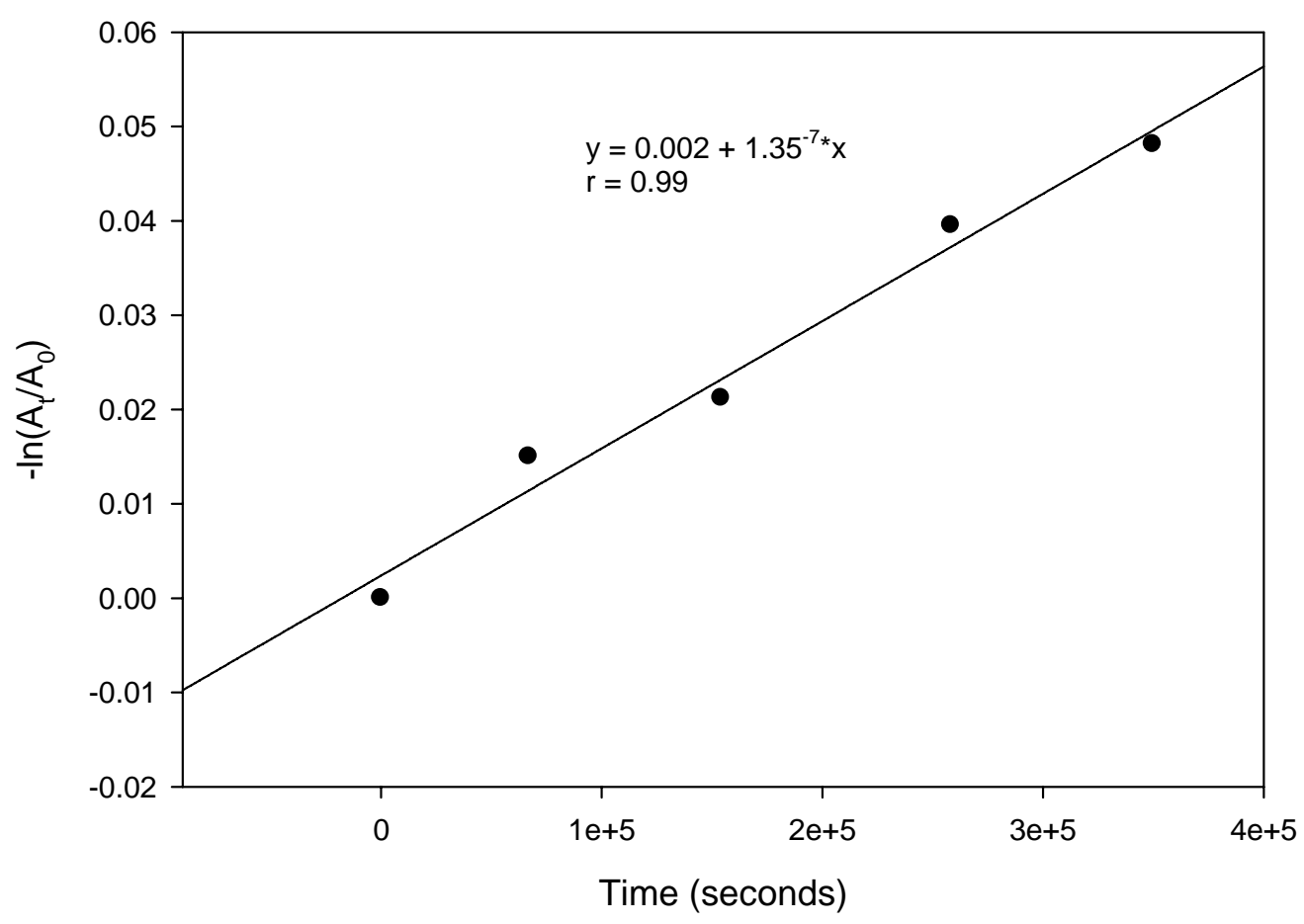

Figure 2. Photobleaching of S-SO-CN dye.

\section{Photobleaching of the S-SO, I-SO, S-SO-CN, I-SO-CN dyes in the presensence of photosensitizer} (Methylene Blue)

$15 \mathrm{~mL}$ of a methanol solution containing dye $(3.33 \mu \mathrm{M})$ and Methylene Blue $(3.33 \mu \mathrm{M})$ were placed in a $20 \mathrm{~mL}$ Borosilicate Glass Scintillation Vial (Fisher catalog \# 03-337-15). The vial was illuminated with the light of a 90W halogen reflector lamp (120 V, 1280 Lumens, 12 Degree Beam Spread). To avoid direct excitation of the dye, light was filtered through a methanol solution containing $6.67 \mu \mathrm{M}$ of each of the dyes: I-SO, S-SO, I-SOCN and S-SO-CN, the length of the filtering solution was $1.0 \mathrm{~cm}$. The distance between the vial and the lamp was $11.0 \mathrm{~cm}$. A fan $(120 \mathrm{~V}, 150 \mathrm{~mm}))$ was used to cool the vial. After $40 \mathrm{~min}$, illumination was stopped and absorbance spectra of the sample were obtained on a Hewlett-Packard 8453 diode array spectrophotometer. 


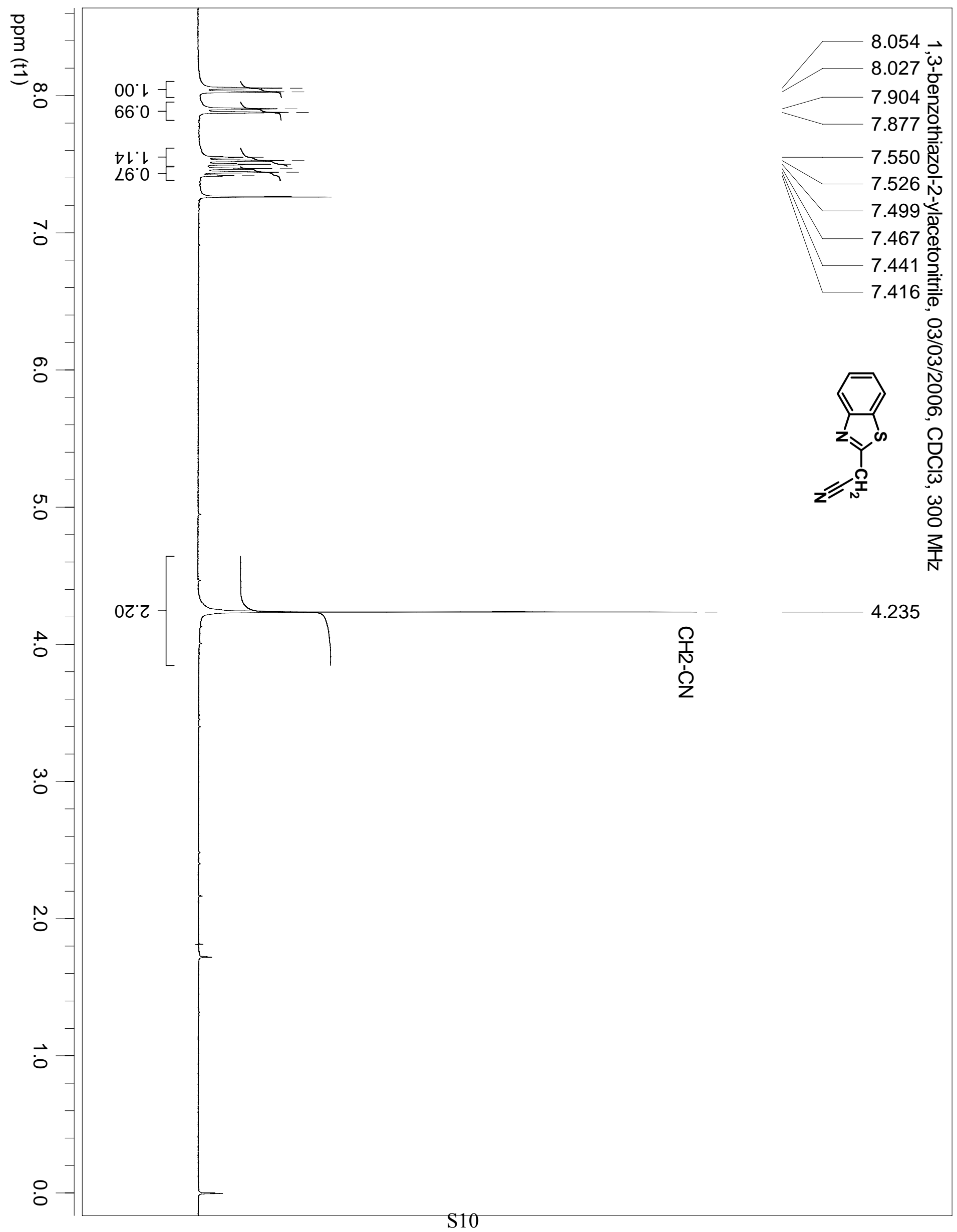




$$
E^{\prime \prime}
$$




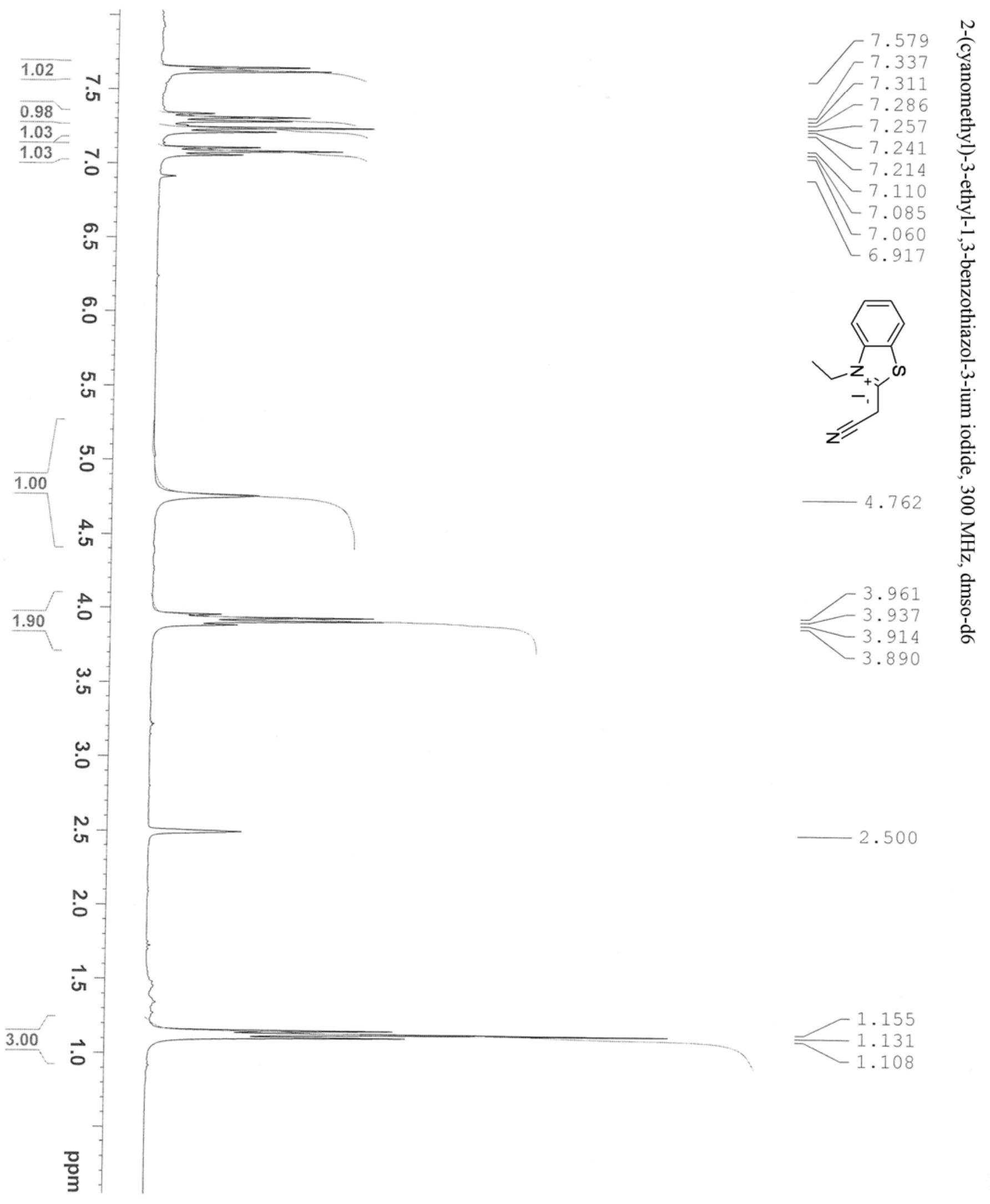




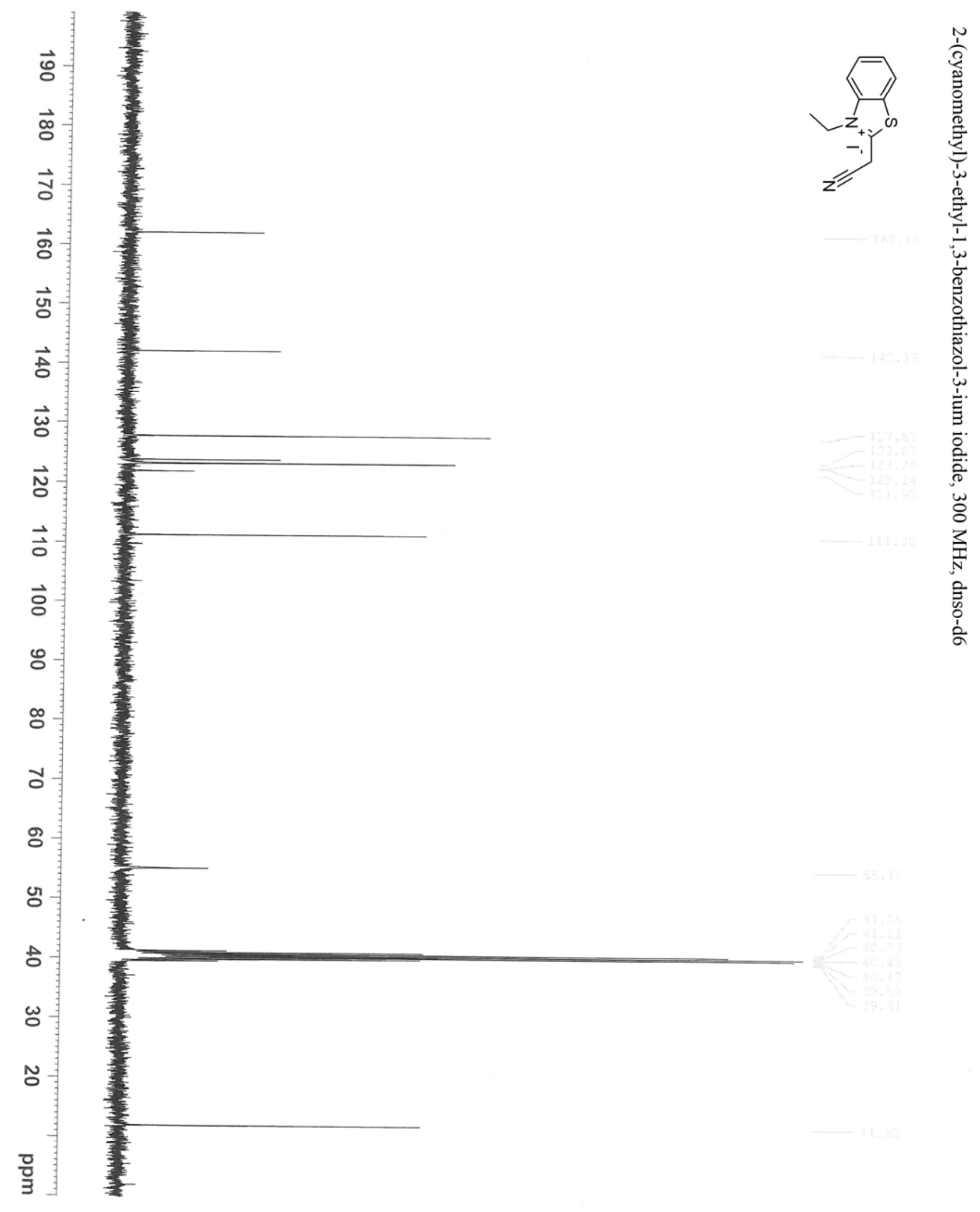




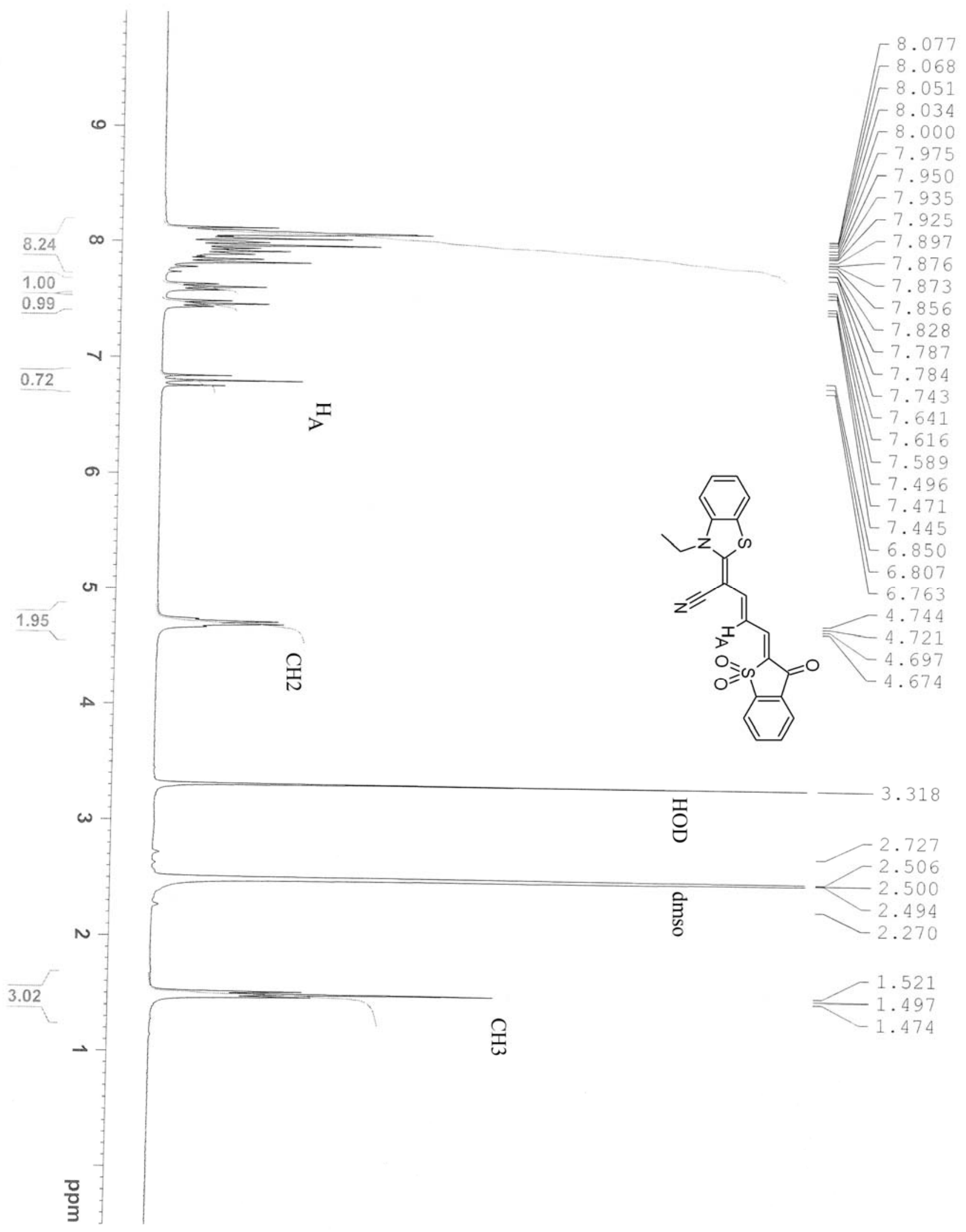

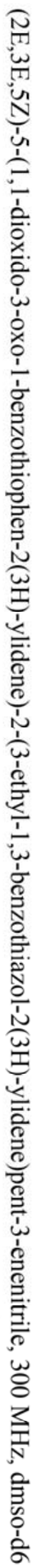




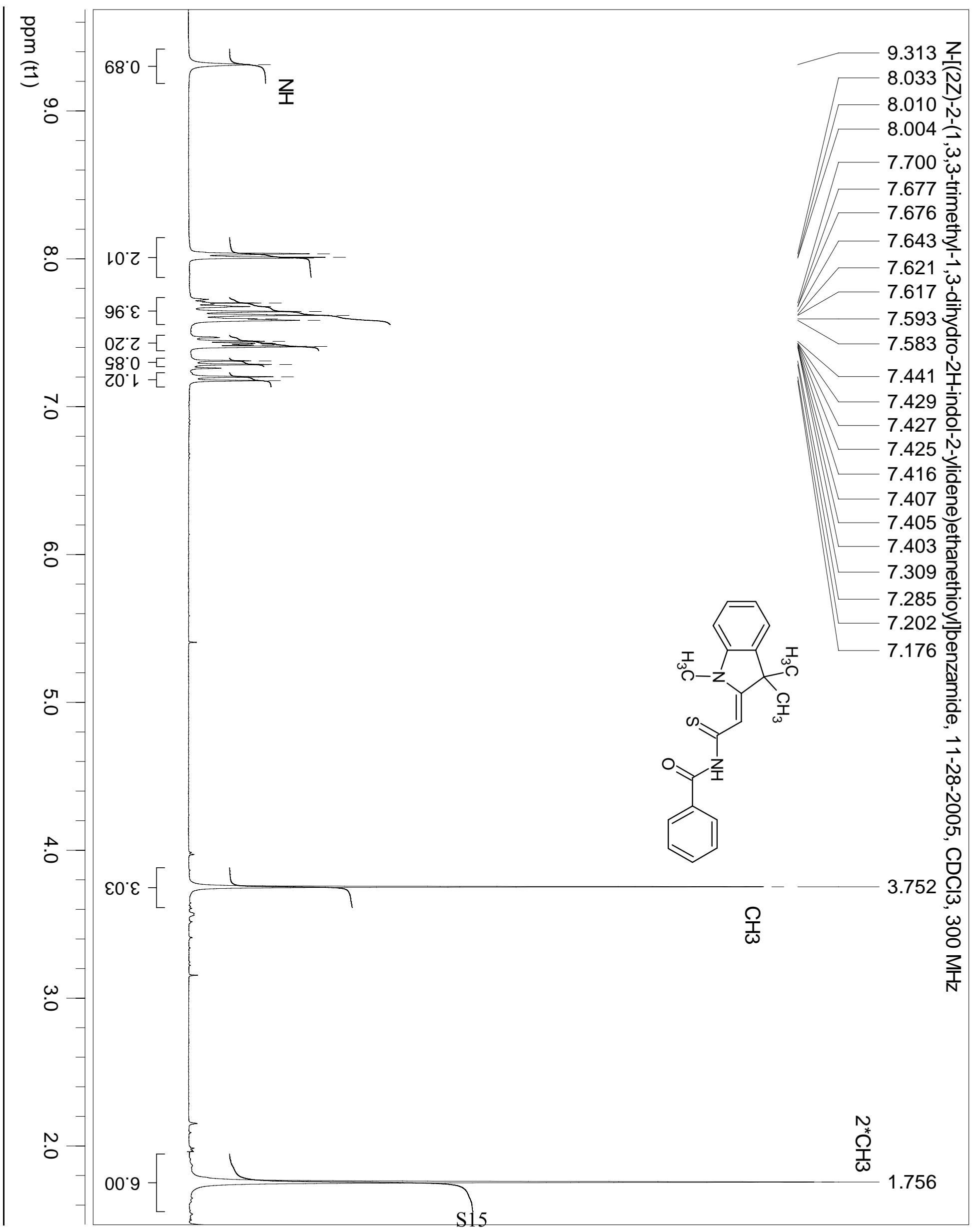




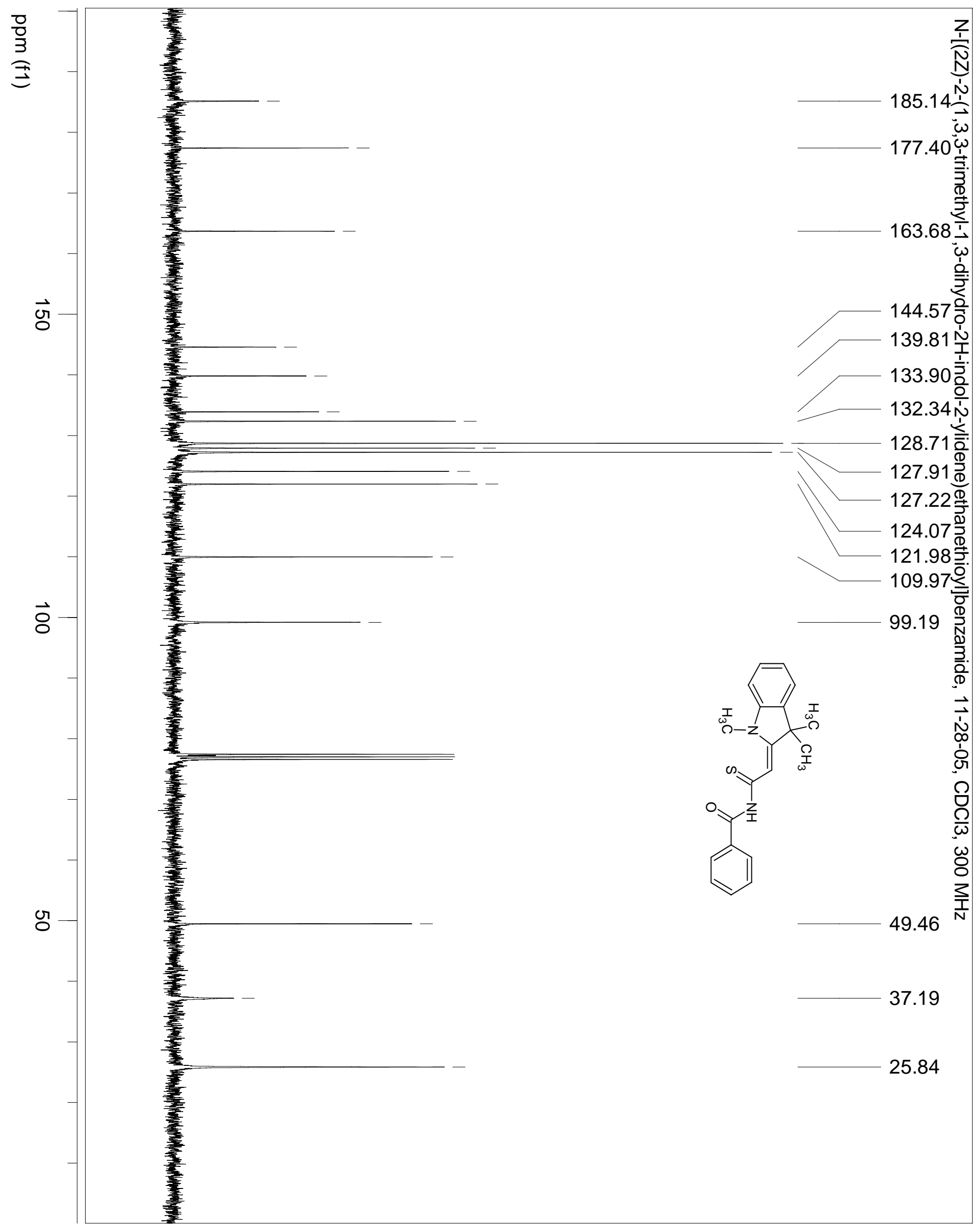




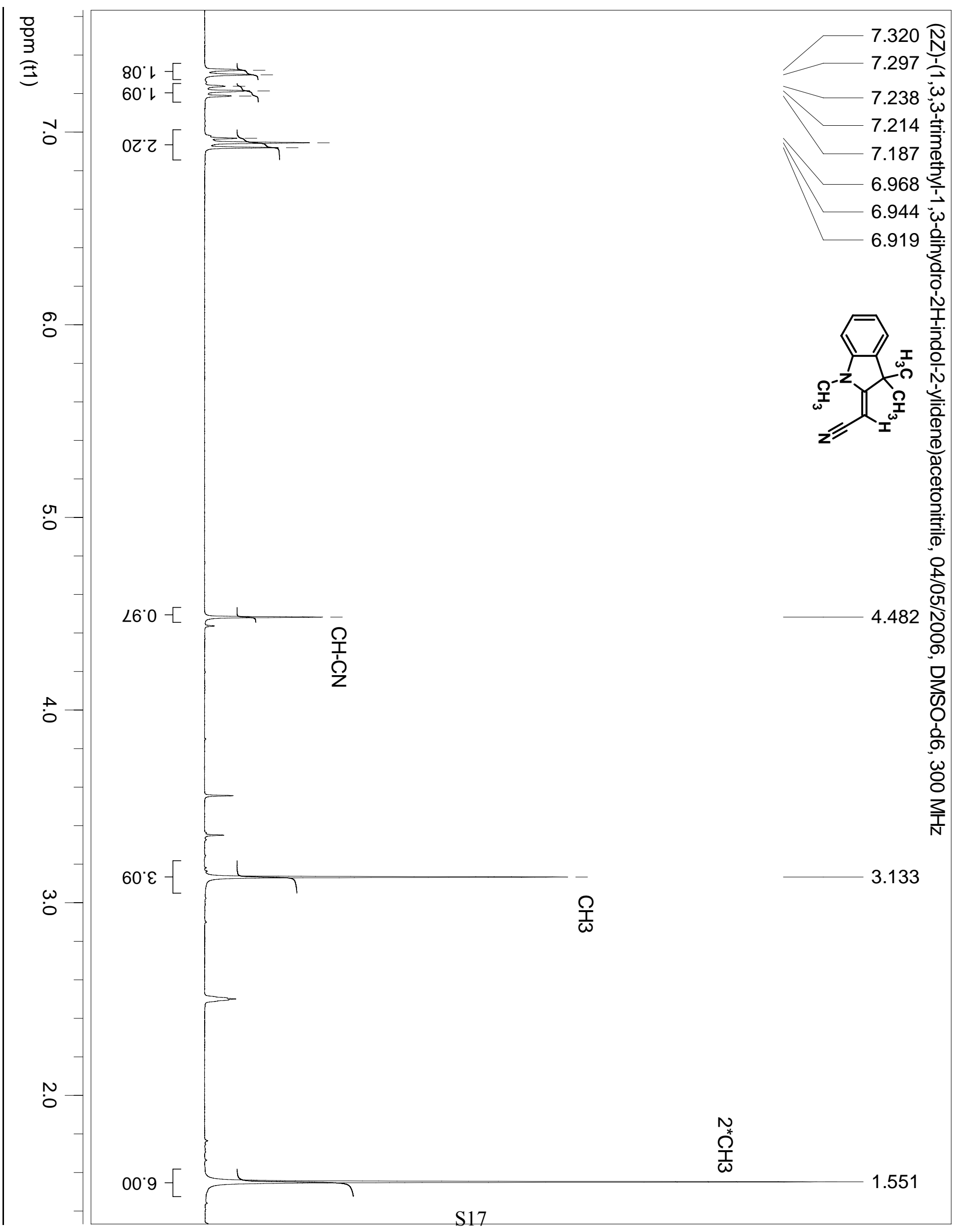




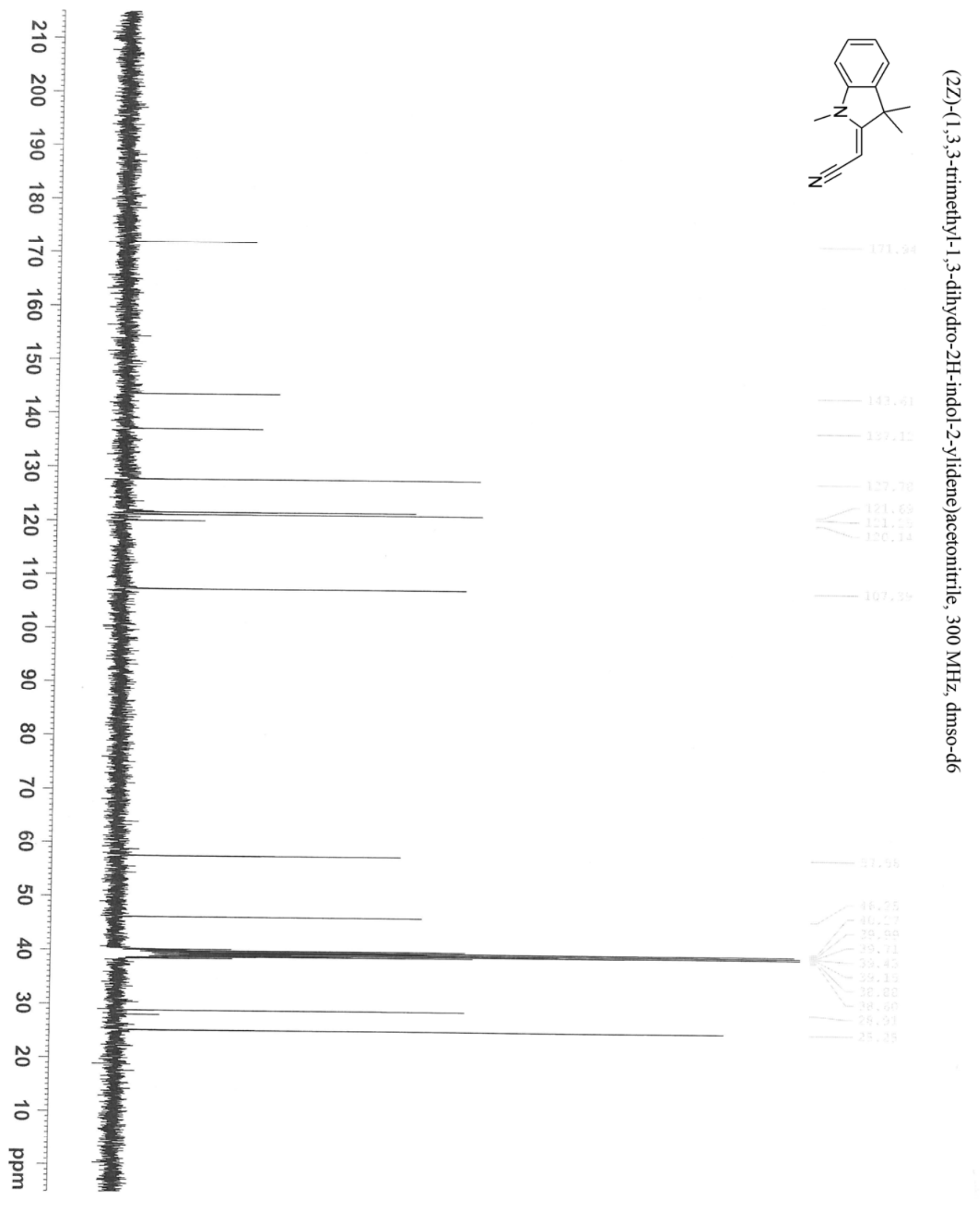




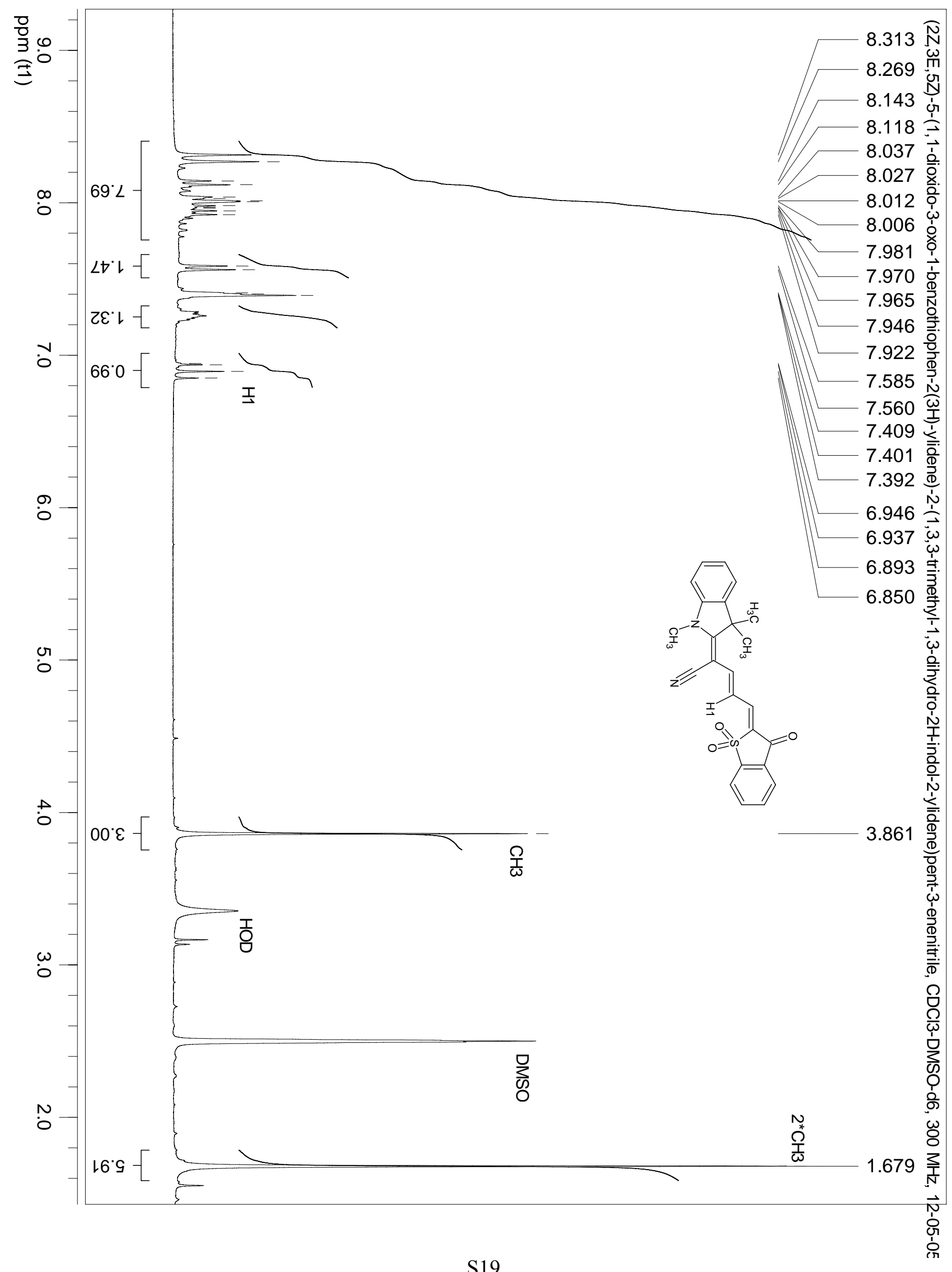


Literature.

1. Toutchkine, A.; Kraynov, V.; Hahn, K. Solvent-Sensitive Dyes to Report Protein Conformational Changes in Living Cells. J. Am. Chem. Soc. 2003, 125, 4132-4145. 